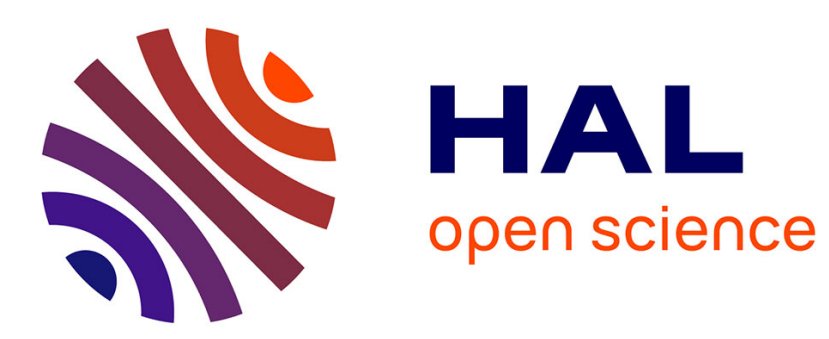

\title{
Gas Phase Composition over Y3Fe5O12
}

O. Goncharov, Yu. Vorobiov, O. Carban

\section{- To cite this version:}

O. Goncharov, Yu. Vorobiov, O. Carban. Gas Phase Composition over Y3Fe5O12. Journal de Physique IV Proceedings, 1997, 07 (C1), pp.C1-185-C1-186. 10.1051/jp4:1997168 . jpa-00255115

\section{HAL Id: jpa-00255115 https://hal.science/jpa-00255115}

Submitted on 1 Jan 1997

HAL is a multi-disciplinary open access archive for the deposit and dissemination of scientific research documents, whether they are published or not. The documents may come from teaching and research institutions in France or abroad, or from public or private research centers.
L'archive ouverte pluridisciplinaire HAL, est destinée au dépôt et à la diffusion de documents scientifiques de niveau recherche, publiés ou non, émanant des établissements d'enseignement et de recherche français ou étrangers, des laboratoires publics ou privés. 


\title{
Gas Phase Composition over $\mathrm{Y}_{3} \mathrm{Fe}_{5} \mathrm{O}_{12}$
}

\author{
O.Yu. Goncharov, Yu.P. Vorobiov and O.V. Carban
}

Physical-Technical Institute, UrB, RAS Kirov Street 132, 426000 Izhevsk, Russia

\begin{abstract}
The account of the gas phase composition over $\mathrm{Y}_{3} \mathrm{Fe}_{5} \mathrm{O}_{12}$ in dependence on temperature and partial pressure of oxygen $\mathrm{PO}_{2}$ at the total pressure in system $\mathrm{P}=10^{5} \mathrm{~Pa}$ was performed with the use of the program Astra.4. Polynomials was offered for account of heats capacities $C_{p}(T)$ solid solutions $\operatorname{Ln}_{n_{-1}-} \mathrm{Ln}_{\mathrm{c}} \mathrm{Fe}_{5} \mathrm{O}_{12}$ ( $\mathrm{Ln}$ : Lanthanide Elements and $\mathrm{Y}$ ). It is shown, that dissociation of garnet results in formation in gas phase of substances: $\mathrm{Fe}, \mathrm{FeO}, \mathrm{YO}_{2}, \mathrm{O}, \mathrm{O}_{2}$, over $900 \mathrm{~K}$ and at further increase of temperature in addition will be formed: $\mathrm{Fe}^{+}, \mathrm{YO} \mathrm{YO}^{+}$. The presence of $\mathrm{FeO}$ (that is ions $\mathrm{Fe}^{2+}$ ) in gas phase is one more proof of reaction: $\mathrm{Y}_{3} \mathrm{Fe}_{5} \mathrm{O}_{12} \rightarrow 3 / 2 \mathrm{O}_{2}+3 \mathrm{~V}_{0}^{-"}+6 \mathrm{Fe}^{\prime}$
\end{abstract}

\section{INTRODUCTION}

The studies of thermodynamic stability of condensed phases in systems $\mathrm{Ln}_{2} \mathrm{O}_{3}-\mathrm{FeO}-\mathrm{Fe}_{2} \mathrm{O}_{3}$ ( $\mathrm{Ln}$ : Lanthanide Elements and $\mathrm{Y})$ are published [1, 2]. The conclusions [2] about comparative stability of $\mathrm{LnFeO}_{3}$ and $\mathrm{Ln}_{3} \mathrm{Fe}_{5} \mathrm{O}_{12}$ were used [3] to synthesize $\mathrm{Nd}_{3} \mathrm{Fe}_{5} \mathrm{O}_{12}, \mathrm{Pr}_{3} \mathrm{Fe}_{5} \mathrm{O}_{12}$. However, a quantitative knowledge of the gas phase composition over $\mathrm{Ln}_{3} \mathrm{Fe}_{5} \mathrm{O}_{12}$ (mass - spectrometer, for example) as a function of temperature and partial pressure is still lacking. This knowledge can be used to bring changes into the technology of ferrite-garnets synthesis and will promote definition of a species of defects in them. The most complete experimental data on main thermodynamic functions and their temperature dependences are available for yttrium iron garnet (YIG) and phases coexisted with it. That is why in present work a composition of a gas phase over $\mathrm{Y}_{3} \mathrm{Fe}_{5} \mathrm{O}_{12}$ is calculated in dependence on temperature and partial pressure of oxygen $\mathrm{Po}_{2}$ at the total pressure in system $\mathrm{P}=10^{5} \mathrm{~Pa}$ and $\mathrm{T}=423 \div 1723 \mathrm{~K}$.

\section{CALCULATION}

The accounts were performed with the use of the program Astra.4 [4]. The program algorithm is based on the decision of system of equations for the equilibrium concentration of the thermodynamic system components. Formation of the following substances in gas phase: $\mathrm{Ar}, \mathrm{O}_{2}, \mathrm{O}, \mathrm{O}_{3}, \mathrm{Fe}, \mathrm{FeO}, \mathrm{Fe}^{+}, \mathrm{Y}, \mathrm{YO}, \mathrm{YO}_{2} \mathrm{YO}^{+}$and in the condensed phase $\mathrm{Fe}, \mathrm{Y}, \mathrm{Fe}_{3} \mathrm{O}_{4}, \mathrm{Fe}_{2} \mathrm{O}_{3}$, $\mathrm{Y}_{2} \mathrm{O}_{3}, \mathrm{YFeO}_{3}, \mathrm{YFe}_{2} \mathrm{O}_{4}, \mathrm{Y}_{3} \mathrm{Fe}_{5} \mathrm{O}_{12}$ has been taken into account. The analysis of phase and chemical equilibrium of thermodynamic system is possible if main thermodynamic properties of its components (heat capacity - Cp, changes of Gibbs free energy $-\Delta G$, enthalpy $-H$, entropy $-\Delta S$, ) are known. The database of the program Astra 4 contains the thermodynamic functions of the majority of components of system. For condensed phases $\mathrm{Y}_{3} \mathrm{Fe}_{5} \mathrm{O}_{12}, \mathrm{YFeO}_{3}, \mathrm{YFe}_{2} \mathrm{O}_{4}$ the thermodynamic functions of reactions of formation from elements $-\Delta \mathrm{G}_{\mathrm{f}}, \Delta \mathrm{H}_{\mathrm{f}}, \Delta \mathrm{S}_{\mathrm{f}}$ [1] were used. The temperature dependences of the thermodynamic functions were calculated using the following expressions:

$$
\Delta \mathrm{H}_{\mathrm{T}}=\Delta \mathrm{H}_{298}+\int \Delta \mathrm{C}_{\mathrm{p}} \mathrm{dT}, \Delta \mathrm{S}_{\mathrm{T}}=\Delta \mathrm{S}_{298}+\int \Delta \mathrm{C}_{\mathrm{p}} \mathrm{T} \mathrm{dT}, \quad \Delta \mathrm{G}_{\mathrm{T}}=\Delta \mathrm{H}_{\mathrm{T}}-\mathrm{T} \Delta \mathrm{S}_{\mathrm{T}}
$$

where $\Delta \mathrm{C}_{p}$ - the difference of heat capacities of products of reaction and initial substances. For yttrium iron garnet of values of heats capacities $C_{p}$ are determined [5] for several temperatures. The temperature dependence $C_{p}(T)$ in researched interval of temperatures was determined by following technique:

a) The deviation $\delta \mathrm{C}_{\mathrm{p}}(\mathrm{T})$ of experimental values of temperature dependences of heats capacities [6] $\mathrm{Ln}_{3} \mathrm{Fe}_{5} \mathrm{O}_{12}\left(\mathrm{Ln}^{3+}=\mathrm{Sm}_{\text {, }}\right.$ $\mathrm{Eu}, \mathrm{Gd}, \mathrm{Tb}, \mathrm{Dy}, \mathrm{Er})$ from sum of heat capacities of oxides were calculated:

$$
\delta \mathrm{C}_{\mathrm{p}}(\mathrm{T})=\mathrm{C}_{\mathrm{p}}(\mathrm{T})-\left\{3 / 2 \mathrm{C}_{\mathrm{p}}\left(\mathrm{Ln}_{2} \mathrm{O}_{3}\right)+5 / 2 \mathrm{C}_{\mathrm{p}}\left(\mathrm{Fe}_{2} \mathrm{O}_{3}\right)\right\}
$$

It is found that the dependences $\delta C_{p}(T)$ have three temperature intervals: $298 \div \mathrm{T}_{\mathrm{K}}$ (Curie), $\mathrm{T}_{\mathrm{K}} \div 955$ and over $955 \mathrm{~T}$. The deviation $\delta \mathrm{C}_{\mathrm{p}}(\mathrm{T})$ in the range of $298 \div \mathrm{T}_{\mathrm{K}}$ is caused [6] by the magnetic contribution to heat capacity of ferrite-garnets, and 
from $\mathrm{T}_{\mathrm{k}}$ up to 955 by phase transition $(\alpha \leftrightarrow \beta)$ in $\mathrm{Fe}_{2} \mathrm{O}_{3}$. For rare earth ferrite-garnets of values $\delta \mathrm{C}_{\mathrm{p}}(\mathrm{T})$ are close and in the first approach their difference is defined by accuracy of the experimental measurements (1\%) [6] and various presence of defects of garnets $(1 \%)$. Hence, the value $\mathrm{Cp}(\mathrm{T})$ can be approximated by polynomials:

$$
\begin{array}{ll}
\delta \mathrm{C}_{p}(\mathrm{~T})=-475.1+4.01 \mathrm{~T}-0.011 \mathrm{~T}^{2}+9.310^{-6} \mathrm{~T}^{3} & \left(\mathrm{~T}=298 \div \mathrm{T}_{\mathrm{K}} \mathrm{K}\right) \\
\delta \mathrm{C}_{\mathrm{p}}(\mathrm{T})=328.1-1.31 \mathrm{~T}+0.002 \mathrm{~T}^{2}+9.8510^{-6} \mathrm{~T}^{3} & \left(\mathrm{~T}=\mathrm{T}_{\mathrm{K}} \div 955 \mathrm{~K}\right) \\
\delta \mathrm{C}_{\mathrm{p}}(\mathrm{T})=2.873-0.0147 \mathrm{~T}+1.4810^{-4} \mathrm{~T}^{2} & (\mathrm{~T}=955 \div 1400 \mathrm{~K})
\end{array}
$$

which dre suitable for account $\mathrm{C}_{\mathrm{p}}(\mathrm{T})$ ferrite-garnets and of solid solutions $\mathrm{Ln}_{3-\mathrm{c}} \mathrm{Ln}_{\mathrm{c}} \mathrm{Fe}_{5} \mathrm{O}_{12}$ -

b) The substitution of polynomials (2) in equation (1) allows to calculate temperature dependence $\mathrm{C}_{\mathrm{p}}(\mathrm{T})$ for $\mathrm{Y}_{3} \mathrm{Fe}_{5} \mathrm{O}_{12}$, which is close to experimental values [5].
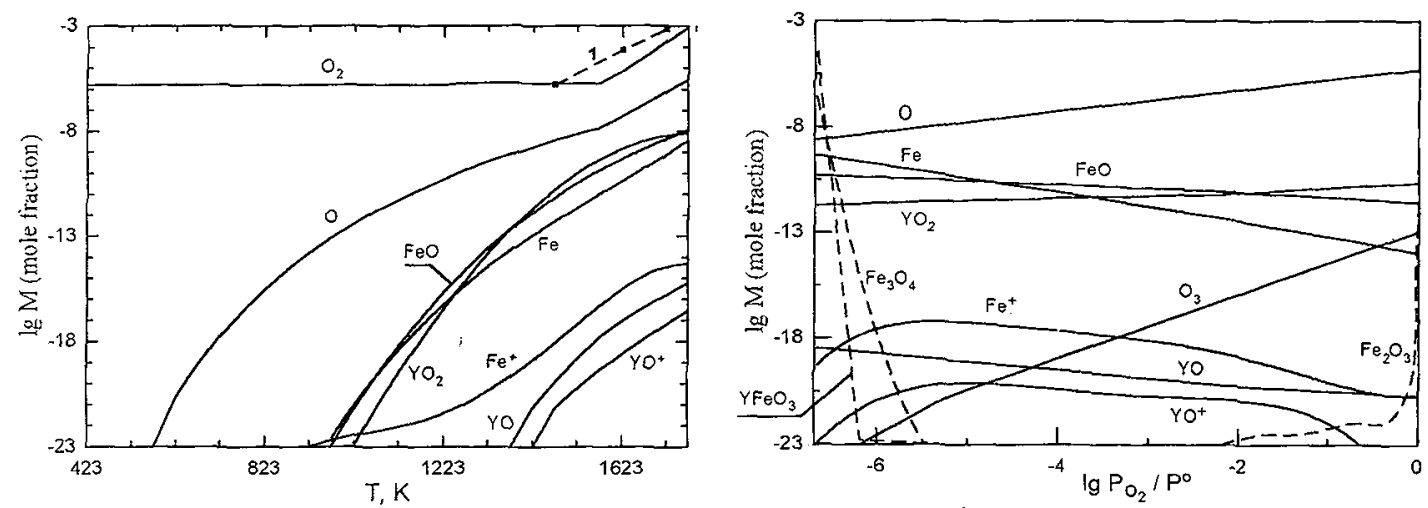

Fig. 1 An equilibrium composition of system YGG-Ar- $\mathrm{O}_{2}$ depend on a) temperature at $P^{0}=10^{5} \mathrm{~Pa}$ (the condensed phase is not shown); line $1-\mathrm{O}_{2}$ in equilibrium with $\mathrm{Y}_{3} \mathrm{Fe}_{5} \mathrm{O}_{12} / \mathrm{YFeO}_{3} / \mathrm{Fe}_{3} \mathrm{O}_{4}[1]$; b) partial pressure of oxygen at $\mathrm{T}=1523 \mathrm{~K}$ (the dotted lines show components of a condensed phase).

\section{RESULTS}

The results of thermodynamic accounts are plotted in fig. 1. It is shown that at the constant pressure $\left(\mathrm{P}^{\circ}=10^{5} \mathrm{~Pa}, \mathrm{Po}_{2}=\right.$ $10^{-6} \mathrm{~Pa}$ ) and temperatures $\mathrm{T}>900 \mathrm{~K}$ to thermal dissociation of garnet begins and in the gas phase (fig. la) components $\mathrm{FeO}$, $\mathrm{Fe}, \mathrm{YO}_{2}, \mathrm{O}, \mathrm{O}_{2}$ appear. At further increase of temperature $\mathrm{Fe}^{+} . \mathrm{YO}, \mathrm{YO}^{+}$are aiso formed. The experimental information about composition of a gas phase over $\mathrm{Y}_{3} \mathrm{Fe}_{5} \mathrm{O}_{12}$ is lacking, therefore comparison of results (fig. 1) is impossible.

The condensed phase composition (in fig. 1 is not shown) changes only at $\mathrm{T}>1273 \mathrm{~K}$. Except garnet there appears the magnetite $\mathrm{Fe}_{3} \mathrm{O}_{4}\left(<0.001\right.$ mole \%), and over $1573 \mathrm{~K}$ the garnet is in equilibrium with $\mathrm{Fe}_{3} \mathrm{O}_{4}\left(0.03\right.$ mole \%) and $\mathrm{YFeO}_{3}(<0.1$ mole \%), that agrees with a phase diagram [7]. The pressure of oxygen, estimated for the equilibrium $\mathrm{Y}_{3} \mathrm{Fe}_{5} \mathrm{O}_{12} / \mathrm{YFeO}_{3} / \mathrm{Fe}_{3} \mathrm{O}_{4}$, is close to experimental [2] (line 1, fig. 1a). The reduction of pressure $\mathrm{Po}_{2} / \mathrm{P}^{\circ}<10^{-6}$ also causes dissociation of garnet on orthoferrite and magnetite, and at increase $\mathrm{Po}_{2}$ up to $\sim 10^{5} \mathrm{~Pa}$ the garnet is in equilibrium with $\mathrm{Fe}_{2} \mathrm{O}_{3}$ (fig. lb, the phase of garnet is not shown), that confirms conclusions [7, 8].

From fig. $1(\mathrm{a}, \mathrm{b})$ it is obvious, that the gas phase over YIG contains oxide FeO $\left(<10^{-8}\right.$ mole fraction at $\left.T=1623 \mathrm{~K}\right)$, the fraction of which enlarges at increase of temperature and reduction of partial pressure of oxygen. Formation of ions Fe ${ }^{2+}$ (in $\mathrm{FeO}$ ) in gas phase makes it possible to assert, that the valency of iron will be changed in condensed phase according to the reaction:

$$
\mathrm{Y}_{3} \mathrm{Fe}_{5} \mathrm{O}_{12}=3 / 2 \mathrm{O}_{2}+3 \mathrm{Vo} \cdot+6 \mathrm{Fe}^{2+}
$$

That coincides data [8] - defects will be formed in $\mathrm{YIG}$ - divalent iron and oxygen vacancy.

\section{References}

[1] Piekarczyk W., Weppner W., Rabenau A., Z. Naturforsch 34A (1979) 430-436.

[2] Kimizuka N., Yamamoto A., Ohashi H., Tadashi S., Toshimori S., J. Solid State Chem. 49 (1983) 65-76.

[3] Fratello V.J., Brandle C.D., Slusky S.E.G., Valentino A.J., Norelli M.P., J. Cryst. Growth. 75 (1986) $281-283$.

[4] Sinjarev G. B., Vatolin N. A., Trusov B. G., Moiseev G. K. Primenenie EVM dlja termodinamicheskih raschetov metallurgicheskih protsessov (Nauka, Moscow, 1982) 264p.

[5] Shchelkotunov V.A., Danilov V.N., Reznitsky L.A., Izv. AN USSR, Neorgan. Mater. 11 (1975) 1633-1637.

[6] Varazashvilli V.S., Tsarahov M.S., Chachanidze G.D., Neorgan. Mater. 26 (1990) 602-604.

[7] Van-Hook H., J. Amer. Cerani. Soc. 45 (1962) 162-166.

[8] Metselaar R., Hyberts M., J. Solid State Chem. 22 (1977) 309-319. 